\title{
DISKURSUS DAN KRITIK TERHADAP TEOLOGI PLURALISME AGAMA DI INDONESIA
}

\author{
Ahmad Khoirul Fata \\ Fakultas Ushuluddin dan Dakwah IAIN Sultan Amai Gorontalo \\ Jl. Gelatik 1 Kota Gorontalo, 96135 \\ e-mail: cakfata@gmail.com
}

\begin{abstract}
Abstrak: Klaim kebenaran mutlak dalam agama sering dianggap sebagai sebab konflik dan kekerasan bernuansa agama. Anggapan ini kemudian melahirkan perlunya penyebaran gagasan pluralisme agama di tengah umat beragama, khususnya umat Islam. Sebagai puncak dari tiga sikap beragama, pluralisme diyakini mampu membawa umat beragama ke kehidupan yang damai dan harmonik karena meyakini adanya kebenaran dalam setiap agama dan keyakinan yang ada. Namun persebaran gagasan ini mengalami kontroversi dan penolakan dari kalangan agamawan sendiri sehingga menjadi tidak efektif dan mengalami titik balik. Tulisan ini mencoba melihat secara kritis gagasan pluralisme agama dan membangun perspektif baru bahwa untuk menjalin harmoni hidup beragama tidak harus meyakini keberadaan kebenaran pada agama dan keyakinan lain. Sikap beragama yang eksklusif juga potensial menjadi dasar hidup harmoni karena sesungguhnya agama (Islam) telah menyiapkan seperangkat doktrinal agar umatnya tetap ramah dan hidup damai bersama umat lain dengan tetap meyakini eksklusivitas kebenaran Islam.
\end{abstract}

\begin{abstract}
Discourse and Critique of Religious Pluralism Theology in Indonesia. The claim of absolute truth of religions is usually considered as the cause of social conflict and violence. From this assumption, many scholars think that we need to spread a religious pluralism theology to the religious communities, especially to Muslim society. As the apex of three religious attitudes, they believe that religious pluralism could make peace and harmony interaction among religious communities. Because of pluralism theology contains a faith that every religions inherent in it equal truth. But the dissemination of religious pluralism was oppossed by religious scholars (theologians), and become controversial within society. This article propose to build a new paradigm in religions theology. This research argues that community can live harmoniously with the others, and at the same time, they believe constantly in absolute truth of their religions. I call this as a exclusive-tolerant theology. In addition, the author argues that Islam has potencies to be an exclusive-tolerant religion, since Islam have given theological basis to harmonious life with different religious groups.
\end{abstract}

Kata Kunci: teologi, agama-agama, pluralisme, eksklusivisme, relativisme 


\section{Pendahuluan}

Dalam kajian filsafat agama dikenal tiga macam cara beragama: eksklusivisme, inklusivisme, dan pluralisme. Eksklusivisme adalah pemahaman bahwa tradisi dan keyakinan tertentu mengajarkan kebenaran dan memiliki jalan keselamatan serta pembebasan. Dalam ekslusivisme terkandung klaim bahwa tradisi dan keyakinan keagamaan yang dianutnya itulah satu-satunya yang benar, sedangkan yang lain salah.

Berbeda dengan itu, inklusivisme merupakan paham yang meyakini bahwa tradisi dan keyakinan keagamaan tertentu memiliki kebenaran yang lengkap (sempurna), namun paham ini tetap memberikan ruang bagi keberadaan kebenaran yang secara parsial terdapat pada tradisi dan keyakinan lain. Sedangkan pluralisme agama merupakan perkembangan lebih jauh dari inklusivisme dengan pengakuan adanya kebenaran dalam tradisi dan keyakinan setiap agama. Paham ketiga ini dianggap sebagai puncak dari sikap keberagamaan umat manusia. Sikap inilah yang diyakini dapat menciptakan kerukunan dan perdamaian di antara umat beragama. ${ }^{1}$

Kategorisasi ini sangat kental nuansa Kristianitasnya. Teolog Kristen John Hick menjelaskan bahwa eksklusivisme merupakan suatu sikap beragama yang mengklaim kebenaran mutlak hanya terdapat dalam tradisi Gereja Kristen. Hanya dalam tradisi kristianitaslah, khususnya dalam tradisi Gereja Katolik, seseorang akan mendapatkan jaminan keselamatan dan pembebasan. Kaidah termasyhur yang menggambarkan sikap tersebut adalah extra ecclessiam nulla sallus (di luar Gereja Katolik tidak ada keselamatan). Keberadaan klaim extra ecclessiam nulla sallus ini tidak terlepas dari adanya doktrin dosa asal yang diterima manusia akibat kesalahan yang dilakukan oleh nenek moyang umat manusia, Adam dan Hawa, ketika berada di surga.

Dosa Adam dan Hawa berupa melanggar larangan memakan buah keabadian itu kemudian diwariskan kepada anak cucunya (umat manusia) sehingga secara azali manusia terlahir dalam kondisi berdosa. Untuk menebus dosa asal itu, Yesus Kristus diturunkan ke dunia sebagai pembebas dan penyelamat umat manusia dari dosa warisan melalui proses penyaliban dirinya. Dengan mengakui misi penebusan yang diemban Yesus Kristus seseorang dapat terbebas dari dosa asal tersebut dan, tentu saja, akan masuk dalam 'wilayah keselamatan dan pembebasan'. Doktrin extra ecclessiam nulla sallus tersebut secara tegas termuat dalam teks-teks Bibel, seperti: "Akulah jalan dan kebenaran dan hidup" (Yohannes

${ }^{1}$ John Hick, "Religious Pluralism," dalam Mircea Eliade (ed.), The Encyclopedia of Religion, Vol. 11 (New York: Mac Millan Publ. Comp., dan London: Collier Mac Millan Publ., 1987), h. 331-333; lihat juga Casram "Membangun Sikap Toleransi Beragama dalam Masyarakat Plural," dalam Wawasan, Vol. 1, No. 2, 2016, h. 187-198; dan Hanafi, "Eksklusivisme, Inklusivisme, dan Pluralisme: Membaca Pola Keberagaman Umat Beriman," dalam al-Fikra, Vol. 10, No. 2, 2011, h. 388-409; Bagus Purnomo, "Toleransi Religius: Antara Pluralisme dan Pluralitas Agama dalam Perspektif al-Qur'an," dalam Suhuf, Vol. 6, No. 1, 2013, h. 83-103; Harda Armayanto, "KristenBarat Membangun Kerukunan," dalam Kalimah, Vol. 11, No. 1, 2013, h. 18-35. 
14: 6), "dan keselamatan tidak ada di dalam siapa pun juga selain di dalam Dia, sebab di bawah kolong langit ini tidak ada nama lain yang diberikan kepada manusia yang olehnya kita dapat diselamatkan (Kisah Para Rasul 4, 12).”2 Sikap beragama seperti ini telah lama tertanam dan berkembang di kalangan Kristen, salah satu tokohnya adalah Karl Barth dan Hendrick Kraemer.

Namun dalam perkembangan selanjutnya terjadi pergeseran sikap di kalangan Gereja Kristen. Semula mereka begitu tegas memegangi klaim kemutlakan kebenaran tradisinya, namun kemudian sikap itu berubah ke sikap yang lebih terbuka terhadap tradisi keagamaan lain. Inilah sikap kedua, yaitu inklusivisme. Inklusivisme dipahami sebagai sikap yang mengakui sesungguhnya misi pembebasan yang diemban Yesus itu ditujukan kepada setiap manusia tanpa terkecuali. Karena itu setiap manusia berhak mendapatkan keselamatan dan pembebasan dari Yesus Kristus. Seseorang yang bersikap inklusif dapat menerima pemahaman bahwa keselamatan dan pembebasan merupakan transformasi gradual dalam kehidupan manusia dan dianggap tidak hanya bertempat dalam tradisi Kristen belaka, tetapi juga dalam konteks semua tradisi keagamaan besar dunia lainnya. Meski demikian, ia tetap meyakini bahwa kerja penyelamatan dan pembebasan menjadi misi istimewa yang berinkarnasi pada diri Yesus dari Nazareth. Namun, walaupun keselamatan akan didapatkan oleh orang yang hidup dalam tradisi Kristen dan tradisi keagamaan lainnya, kaum inklusivis tetap meyakini adanya perbedaan antara orang-orang yang berada di dalam tradisi Kristen dengan mereka yang berada di luar tradisi tersebut. Karl Rahner menyebut orang-orang yang hidup dalam tradisi lain sebagai 'anonymous Christian' (Kristen Anonim), yaitu orang yang secara eksplisit tidak berkeyakinan Kristen, tetapi secara sadar atau tidak, hidup dalam kehendak Tuhan. Orang seperti ini bisa sebagai Muslim, Hindu, atau Yahudi. ${ }^{3}$

Setelah mengalami perubahan sikap dari eksklusif ke inklusif, tradisi Gereja pun kembali berubah ke arah sikap pluralis. Pluralisme diyakini sebagai kritik terhadap inklusivisme. Meski dalam sikap inklusif telah secara terbuka diakui adanya keselamatan untuk tradisi keagamaan lain di luar Gereja, namun cara pandang dalam melihat tradisi luar itu terpaku pada perspektif Kristenitas. Berbeda dengan inklusivisme, sikap pluralistik mengandung

${ }^{2}$ Anonim, al-Kitab (Jakarta: Lembaga al-Kitab Indonesia, 1988), h. 139 dan 154. Tentang dogma dosa warisan dalam Kristen Katolik lihat Abu Bakar, "Konsep Pengampunan Dosa dalam Kristen Katolik," dalam Toleransi, Vol. 3, No. 2, 2001, h. 198-206; Tarpin, "Pandangan Kristen tentang Dosa: Asal Muasal dan Cara Menebusnya," dalam Jurnal Ushuluddin, Vol. 16, No. 2, 2010, h. 221-233; Eben Munthe, "Dosa Menurut Teologi Paulus," dalam Pneumatikos, Vol. 1, No. 1, 2010, h. 31-40; Bartholomeus Diaz Nainggolan, "Dosa Asal Berdasarkan Eksegesis Surat Roma 5: 12-21," dalam Koinonia, Vol. 10, No. 2, 2015, h. 13-41; Happy Susanto, "Kritisisme Sejarah Teologi Barat," dalam Tsaqafah: Jurnal Peradaban Islam, Vol. 7, No. 2, 2011, h. 299-316.

${ }^{3}$ Arqom Kuswanjono, "Pluralisme Pancasila," dalam Jurnal Filsafat, Vol. 39 No. 1, 2006, h. 78; Kees de Jong, "Hidup Rukun Sebagai Orang Kristen: Spiritualitas dari Segi Theologia Religionum," dalam Gema Teologi, Vol. 30, No. 2, 2006, catatan kaki No. 14. 
asumsi adanya kebenaran yang sama-setara dalam setiap tradisi keagamaan. Setiap tradisi keagamaan yang ada dianggap sebagai jalan-jalan yang sah untuk mendapatkan keselamatan. ${ }^{4}$

Eksklusivisme seringkali digambarkan sebagai cara beragama yang salah (atau sekurangnya tidak tepat), suatu sikap beragama yang intoleran dan dinilai menjadi sumber konflik antar umat beragama. Karenanya banyak pihak yang menganjurkan umat beragama untuk meninggalkan cara beragama tersebut dan beralih sikap ke pluralis, minimal berada di level inklusif. Namun tuduhan dan ajakan itu menimbulkan banyak penentangan dari berbagai pihak. Dalam konteks Indonesia, reaksi penolakan paling keras tercermin dari fatwa Majelis Ulama Indonesia (MUI) tentang keharaman umat Muslim menganut paham pluralisme, liberalisme, dan sekularisme pada tahun 2005 lalu. ${ }^{5}$ Paham pluralisme agama dinilai oleh para penentangnya dapat menjerumuskan umat beragama (khususnya Islam) ke dalam paham relativisme kebenaran agama-agama. ${ }^{6}$

Dengan mempertimbangkan keberatan-keberatan terhadap paham pluralisme, tampak bahwa sebenarnya tanpa mengadopsi paham ini pun umat Islam tetap bisa mengembangkan suatu sikap beragama yang toleran dan ramah terhadap umat beragama lain. Jika tujuan utama sikap inklusif dan pluralis adalah mengembangkan keberagamaan yang damai, maka sesungguhnya umat Islam tetap bisa meyakini keunggulan dan eksklusivitas agamanya atas agama-agama yang lain, dan di saat bersamaan tetap mampu hidup rukun dan damai dengan umat lain. Dengan demikian, bangunan keberagamaan yang eksklusif namun tetap toleran sangat perlu diwujudkan agar umat Islam bisa menjalin hubungan harmonis dengan umat-umat agama lain tanpa perlu dihinggapi kekhawatiran jatuh pada relativisme agama sebagaimana yang diwanti-wanti oleh MUI.

Artikel ini adalah bagian dari penelitian penulis dengan judul Liberalisme Islam di Indonesia: Gagasan dan Tanggapan tentang Pluralisme Agama pada Program Pascasarjana UIN Sunan Ampel Surabaya yang dikembangkan dan membahas tiga masalah: bagaimanakah konstruk teologi pluralisme agama?; Apakah pluralisme agama bisa menjadi solusi bagi konflik antar umat beragama atau justru menjadi problem tersendiri bagi doktrin keagamaan?; Apakah mungkin dalam Islam dikembangkan suatu teologi yang eksklusif namun tetap ramah terhadap keberadaan umat agama lain?.

${ }^{4}$ Hick, "Religious Pluralism," h. 331-333.

${ }^{5}$ Fatwa MUI tentang Sekularisme, Liberalisme dan Pluralisme Agama mendapat banyak kritikan dari kaum liberal. Lihat Mun'im Sirry, "Fatwas and Their Controversy: The Case of the Council of Indonesian Ulama (MUI)," dalam Journal of the Southeast Asian Studies, Vol. 4 4, Issue 1, 2013, h. 100-117; M. Hilaly Basya, "The Concept of Pluralism in Indonesia: a Study of MUI's Fatwa and the Debate Among Muslim Scholars," dalam Indonesian Journal of Islam and Muslim Societies (IJIMS), Vol. 1, No. 1, 2011, h. 69-93. Namun demikian, banyak juga yang membelanya. Lihat Ahmad Khoirul Fata dan Fauzan, "Kritik 'Insist' terhadap Gagasan Pluralisme Agama," dalam Kalam, Vol. 11, No. 1, 2017, h. 31-56; Ahmad Khoirul Fata, "Insists dan Gerakan Anti Liberalisme Islam di Indonesia," dalam Jurnal Kajian dan Pengembangan Manajemen Dakwah, Vol. 4, No. 1, 2014, h. 65-82.

${ }^{6}$ Lihat Fata dan Fauzan, "Kritik 'Insist' Terhadap Gagasan Pluralisme Agama," h. 31-56. 


\section{Menggugat Klaim Kebenaran Agama}

Konflik yang terjadi dunia sering mengatasnamakan agama dan melibatkan umatnya. Tidak heran jika banyak kalangan menuduh agama sebagai sebab bagi konflik-konflik tersebut. ${ }^{7}$ Catatan sejarah dunia dapat ditunjuk untuk memperkuat tuduhan tersebut, semisal Perang Salib yang melibatkan umat Kristen versus Muslim yang berlangsung selama berabadabad dan penuh dengan tragedi, konflik komunitas Hindu dan Muslim di India, Buddha dan Muslim di Myanmar, Kristen dan Kristen di Irlandia (dan Eropa secara umum selama abad pertengahan), pembantaian etnis Muslim oleh komunitas Kristen di Bosnia Herzegovina, pemberontakan Tamil (Hindu) di tengah masyarakat Srilanka yang mayoritas beragama Buddha, agresi Amerika dan sekutunya di Afghanistan dan Irak (meski bermotif ekonomi politik, tetapi seringkali dikaitkan dengan agama), dan konflik abadi antara Israel (Yahudi) dan Palestina (Islam-Kristen). Di Indonesia juga terjadi konflik bernuansa agama, seperti kasus perang sipil antara komunitas Kristen versus Muslim di Ambon di awal-awal era reformasi, atau peristiwa pembakaran masjid dan penyerangan umat Islam saat Salat Idul Fitri di Tolikara Provinsi Papua oleh massa Gereja Injili di Indonesia (GIDI). Bukan hanya antar umat beragama, konflik dan kekerasan intra umat beragama juga kerap terjadi di Indonesia, seperti kasus penyerangan terhadap Ahmadiyah, Syiah, Hizbut Tahrir Indonesia (HTI), atau jamaah Majelis Tafsir al-Qur'an (MTA) di berbagai daerah.

Sebenarnya kurang tepat menuduh agama sebagai satu-satunya penyebab konflik. Karena konflik yang terjadi seringkali bersifat kompleks dan multidimensi. Faktor historis, politik, dan ekonomi, sering bertumpang tindih dengan sikap beragama yang eksklusif. Sarlito Wirawan Sarwono menengarai, potensi konflik komunal di negeri ini berurat dan berakar pada diskriminasi yang dilakukan pemerintah kolonial Hindia Belanda terhadap komunitas pribumi Muslim yang di kemudian hari diperparah oleh sikap eksklusif umat beragama. Sikap eksklusif itu terbentuk oleh anggapan adanya ancaman dari satu komunitas agama terhadap komunitas agama lainnya (adanya kecurigaan yang kuat antara komunitas agama). Hal itu semakin diperkuat oleh aktivitas keagamaan yang hanya meneguhkan keyakinan dan keimanan pemeluknya secara internal, namun di sisi lain, menipiskan ikatan dengan komunitas lainnya. ${ }^{8}$ Sikap ini diyakini dapat

${ }^{7}$ Tuduhan seperti ini banyak ditemui di berbagai tulisan. Lihat Firdaus M. Yunus, "Konflik Agama di Indonesia," dalam Substantia, Vol. 16, No. 2, 2014, h. 220; Abu Hapsin, Komarudin dan M. Arja Amroni, "Urgensi Regulasi Penyelesaian Konflik Umat Beragama: Perspektif Tokoh Lintas Agama," dalam Walisongo, Vol. 22, No. 2, 2014, h. 353; Taufik Adnan Amal, "Masalah Keberagamaan di Tengah Keragaman," dalam Abd. Rohim Ghazali dan Saleh Partaonan Daulay (ed.), Muhammadiyah dan Politik Islam Inklusif: 70 Tahun Ahmad Syafii Maarif (Jakarta: Maarif Institute, 2005), h. 71-72.

${ }^{8}$ Sarlito Wirawan Sarwono, "Hubungan Antar Agama dalam Pandangan Psikologi," dalam Devi Setya Wibawa, et al (ed.), Dialog Antar Agama (Jakarta: Pusat Kajian Pembangunan Masyarakat UNIKA Atma Jaya, 1998), h. 302-208. Sikap eksklusif beragama menjadi tertuduh utama dalam terjadinya berbagai konflik sosial. Kesimpulan ini tampak jelas dalam berbagai tulisan kalangan Islam liberal. 
menimbulkan bermacam bentuk kekerasan dan konflik keagamaan yang laten. Karena itu, Nurcholish Madjid meyakini tidak ada masa depan dalam keberagamaan yang dikembangkan secara eksklusif. Cepat atau lambat eksklusivisme akan membawa manusia pada kehancuran. ${ }^{9}$

Dengan mengutip tesis Hugh Goddard, Budhy Munawar-Rahman menyatakan bahwa agama memiliki wajah paradoksal. Hal ini akibat dari penerapan standar ganda (double standard) dalam relasi yang dibangun oleh umat beragama. Di satu sisi agama menyeru dan mengajarkan perdamaian, namun di sisi lain terdapat banyak konflik yang membawa nama agama. Dalam konteks konflik Kristen-Islam, Rahman melihat kedua komunitas itu selalu menerapkan standar yang ideal dan normatif untuk melihat diri sendiri, dan menerapkan standar yang berbasis realitas dan historis ketika memandang agama lainnya. Standar ganda seperti itu akan memunculkan prasangka-prasangka teologis dan pada akhirnya memperkeruh relasi antar komunitas beragama. ${ }^{10}$

Rahman mencontohkan dalam bidang teologi, baik Kristen maupun Muslim seringkali melihat doktrin agamanya sebagai yang paling benar dan murni yang bersumber dari Tuhan, sementara agama lain hanya sekadar konstruksi manusia. Atau meskipun bersumber dari Tuhan tetapi sudah dirusak dan atau dipalsukan oleh manusia. Secara historis standar, jelas Rahman, ganda sering dipakai untuk men-judge agama lain sebagai memiliki derajat otentisitas teologis di bawah agama yang dianut. Dalam hubungan yang dipenuhi standar ganda tersebut, terkandung klaim kebenaran absolut (absolute truth claim) pada agama sendiri. Rahman pun berkesimpulan bahwa sikap dan klaim ini menunjukkan ketidakkritisan cara berpikir dalam beragama, dan lebih dari itu, menjadi sebab terjadinya konflik antar agama. ${ }^{11}$

Bagi Charles Kimball absolute truth claim merupakan sesuatu yang secara alami berada dalam setiap agama dan menjadi dasar dari keseluruhan struktur agama. Meski demikian, Kimball menyebut bahwa klaim kebenaran agama yang otentik tidak pernah begitu kaku dan eksklusif. Namun ketika interpretasi tertentu atas klaim tersebut menjadi proposisi-proposisi yang menuntut kebenaran tunggal dan diperlakukan sebagai doktrin yang kaku, kecenderungan terhadap penyelewengan dalam agama dapat muncul dengan mudah. Lebih jauh Kimball menilai bahwa klaim kebenaran yang telah diselewengkan tersebut tidak memiliki kesadaran keterbatasan yang dimiliki manusia dalam usaha mencari h. 60 .

${ }^{9}$ Nurcholish Madjid, Cendekiawan \& Religiusitas Masyarakat (Jakarta: Paramadina, 1999),

${ }^{10}$ Buku itu telah diterjemahkan ke Bahasa Indonesia berjudul Menepis Standar Ganda: Membangun Saling Pengertian Muslim-Kristen, terj. Ali Noer Zaman (Yogyakarta: Qalam, 2000). Mengenai pernyataan Goddard tersebut lihat "Kata Pengantar".

${ }^{11}$ Hatim Gazali, "Agama dalam Cetakan Baru," dalam Jawa Pos (7 Desember 2003). Lihat juga Budhy Munawar Rahman, Islam Pluralis: Wacana Kesetaraan Kaum Beriman (Jakarta: Paramadina, 2001), h. 34-35. 
dan mengartikulasikan kebenaran agama. ${ }^{12}$ Selain merugikan agama lain, klaim tersebut juga bisa merugikan dirinya sendiri karena akan mempersempit ruang bagi masuknya kebenaran-kebenaran baru yang dapat memperkaya dan melapangkan kehidupan. ${ }^{13}$

\section{Dari Eksklusivisme ke Pluralisme}

Cara beragama yang eksklusif dianggap Rahman merupakan problem historis yang selalu diwarisi masyarakat beragama. Untuk itu, ia menekankan perlunya teologi yang ramah terhadap agama lain. Teologi seperti ini, menurutnya, dibangun dari kesadaran akan keberadaan diri sendiri di tengah agama-agama lain agar dapat dilakukan dialog antar umat beragama. Dengan demikian, pemeluk suatu agama dapat mencoba pemahaman cara baru yang lebih mendalam tentang bagaimana Tuhan memiliki jalan penyelamatan. Poin penting teologi ramah agama, menurut Rahman, terletak pada pertanyaan: "apakah terdapat kebenaran dan keselamatan dalam agama dan keyakinan lain?". Pertanyaanpertanyaan ini berakar pada satu pertanyaan pokok: "Apakah kita menyembah Tuhan yang sama?". ${ }^{14}$ Secara lebih sederhana, Komaruddin Hidayat merumuskan pertanyaan untuk teologi model ini sebagai berikut: "Benarkah jalan keselamatan Tuhan hanya dimonopoli oleh satu tradisi agama?."15

Rahman pun menganggap teologi inklusif bahkan pluralis sebagai formulasi teologi ramah agama-agama, dan menjadi jawaban bagi pertanyaan-pertanyaan tersebut. ${ }^{16}$ Menurutnya teologi seperti inilah yang bisa menempatkan manusia pada posisi sederajat tanpa melihat latar belakang agama, budaya, suku, dan identitas komunal lainnya. Selain itu juga membuka kemungkinan adanya kebenaran pada komunitas agama lain dan kebersamaan dalam menanggung kewajiban menciptakan perdamaian dan ketenteraman dalam kehidupan. ${ }^{17}$

Teologi pluralisme agama yang ditawarkan tokoh-tokoh tersebut dibangun atas beberapa prinsip. Pertama, logika bahwa Yang Satu (Tuhan) dapat dipahami dan diyakini dalam bermacam bentuk dan penafsiran. Artinya, Yang Maha Kuasa itu dapat dipahami oleh para penganut agama-agama yang ada secara berbeda-beda. Namun semua itu tetap merujuk ke satu keyakinan bahwa Yang Maha Kuasa itu hanya satu. Keyakinan seperti ini,

\section{4-85.}

${ }^{12}$ Charles Kimball, Kala Agama Jadi Bencana, terj. Nurhadi (Bandung: Mizan, 2003), h.

${ }^{13}$ Komaruddin Hidayat dan M. Wahyuni Nafis, Agama Masa Depan: Perspektif Filsafat Perennial (Jakarta: Gramedia, 2003), h. 50.

${ }^{14}$ Rahman, Islam Pluralis, h. 32-33.

${ }^{15}$ Komaruddin Hidayat, "Membangun Teologi Dialogis dan Inklusivistik," dalam Komaruddin Hidayat dan Ahmad Gaus AF (ed.), Passing Over: Melintasi Batas Agama (Jakarta: Gramedia, 2001), h. 38.

${ }^{16}$ Rahman, Islam Pluralis, h. 44-52.

${ }^{17}$ Gazali, "Agama dalam Cetakan Baru." 
menurut mereka merupakan substansi keimanan semua agama yang dicerap oleh manusia secara beragam sebagai konsekuensi logis ketika yang terbatas mencoba memahami Yang Mutlak (Tuhan).

Kedua, bahwa keragaman penafsiran dan pemahaman mengenai Yang Satu itu hanyalah sekadar alat dan jalan menuju kepada hakikat Yang Absolut. Prinsip ini mereka nilai penting karena selain memberikan pondasi bagi pandangan bahwa pluralisme merupakan suatu kemestian, juga sebagai upaya untuk mencegah adanya absolutisme pada setiap bentuk pemahaman dan tradisi keagamaan.

Ketiga, meskipun terbatas, pengalaman keagamaan yang partikular tetap harus diyakini memiliki nilai yang absolut bagi pemeluknya. Prinsip ini merupakan komitmen bahwa keagamaan yang mendalam sangat diperlukan dan berfungsi sebagai kriteria yang mengabsahkan serta memberikan makna terdalam dari seluruh pengalaman pribadi seseorang.

Meski demikian, satu hal yang penting untuk dicatat di sini, hal itu bukan berarti menoleransi adanya pemaksaan terhadap pihak lain untuk meyakini dan mengakui keyakinan keagamaan seseorang. Sikap itu harus tetap dibarengi dengan pengakuan bahwa orang lain juga memiliki komitmen mutlak terhadap pengalaman keagamaan partikularnya sebagaimana yang diyakini. Ungkapan sederhana yang mereka gunakan untuk menyatakan hal ini adalah "absolut yang relatif (relatively absolute)," bahwa kemutlakan pengalaman keagamaan setiap orang sesungguhnya bersifat relatively absolute. ${ }^{18}$

Prinsip-prinsip tersebut kemudian dirumuskan dalam pernyataan, "other religions speak of different but equally valid truth" (agama-agama lain mengungkapkan perbedaan, tetapi kebenarannya sama-sama valid), "other religions are equally valid ways to the same truth," (agama-agama yang lain merupakan jalan-jalan yang sama-sama valid menuju kepada kebenaran yang sama), atau "each religion expresses an important part of the truth," (setiap agama mengungkapkan satu bagian penting dari kebenaran). ${ }^{19}$

Dalam konteks keragaman jalan menuju Yang Absolut inilah, Rahman melihat, dengan meminjam gagasan Frithjof Schoun, bahwa agama-agama yang ada di dunia ini sesungguhnya terdiri atas dua unsur: esoterik dan eksoterik. Unsur esoterik menjadi titik temu semua agama secara transendental, karena hal itu adalah the heart of religions (jatung atau inti dari setiap agama-agama). Menurut Rahman, di aspek ini tidak ada perbedaan di antara satu agama dengan agama lainnya. Namun pada aspek eksoterik, jelasnya, kebenaran yang tunggal tersebut terpecah-pecah sebagai akibat dari keragaman spektrum pemahaman setiap orang terhadap yang tunggal itu. Perbedaan penangkapan

${ }^{18}$ Muhammad Wahyuni Nafis, "Referensi Historis Bagi Dialog Antaragama," dalam Komaruddin Hidayat dan Ahmad Gaus AF (ed.), Passing Over: Melintasi Batas Agama (Jakarta: Gramedia, 2001), h. 93-94.

${ }^{19}$ Rahman, Islam Pluralis, h. 50-52. 
ini terjadi karena adanya keragaman dimensi, bahasa dan cara pandang. Pada titik inilah terletak sebab terjadinya perbedaan agama-agama.

Rahman mengibaratkan sisi esoterik dan eksoterik sebagai pelangi dengan beragam warnanya, tetapi semua warna itu memiliki dasar yang sama: warna putih. Warna-warna yang beragam itu muncul dari warna putih karena terjadinya pembelokan. Dalam ungkapan lain, Rahman menjelaskan bahwa setiap warna-warna yang ada itu sesungguhnya mengandung warna putih. Pada dasarnya, semua agama itu mempunyai warna dasar yang sama, yang tidak terlihat dari warna luarnya yang beragam. Dalam perspektif inilah Rahman mengibaratkan Islam sebagai warna hijau, Kristen warna biru, dan seterusnya. Meski berbeda, pada dasarnya semua warna-warni agama itu berasal dari unsur 'warna putih.' Warna ini sering disebut sebagai warna primordial dari agama. Inilah yang disebut Rahman sebagai aspek esoterisme agama-agama. Rahman juga mengibaratkan dengan air yang memiliki substansi yang sama, meski dalam wadah yang berbeda-beda. Juga diibaratkan dengan roda yang memiliki kesatuan di pusatnya dan perbedaan/kerenggangan di pinggirnya. ${ }^{20}$

Pembelokan warna tersebut, menurut Mun'im A. Sirry, terjadi karena keterbatasan manusia dalam mempersepsikan Tuhan Yang Absolut. Yang relatif tidak bisa menangkap Yang Absolut secara mutlak, kecuali sebatas kerelatifannya. Ini kaidah yang dipegang erat pendukung gagasan pluralisme agama. Alasannya, karena manusia yang secara ontologis relatif mustahil mampu mempersepsikan Tuhan Yang Maha Mutlak. Perbedaan ontologis itu memastikan adanya 'jarak' yang amat jauh antara manusia dan Tuhan. Menurut Sirry, jarak itu hanya bisa dimediasi melalui simbol-simbol sehingga manusia menangkapnya seolah-olah ada beragam bentuk Tuhan. Di titik inilah Komaruddin Hidayat menganggap terlalu sombong bila ada orang yang mengaku paham dan kenal Tuhan. Keterbatasan manusia sebagai makhluk yang relatif dalam mempersepsikan Yang Absolut itu seringkali mereka tamsilkan dengan cerita perbedaan persepsi tiga orang buta terhadap seekor gajah yang sama. ${ }^{21}$

Tuhan dalam batasan relativitas manusia itu disebut oleh Kautsar Azhari Noer sebagai "Tuhan kepercayaan." Noer mendefinisikan Tuhan kepercayaan sebagai gambar, bentuk, konsep, ide, pemikiran, atau gagasan tentang Tuhan yang diciptakan oleh rasio manusia atau taklidnya. Menurutnya, Tuhan model ini bukanlah termasuk Tuhan yang sesungguhnya.

${ }^{20} I b i d$. , Lihat juga Hidayat dan Nafis, Agama Masa Depan, h. 52-53; "Sukidi: di Amerika Saya Menemukan Islam," dalam http://islamlib.com/id/index.php?page=article\&id=846, 10 Juli 2005; Sukidi, Teologi Inklusif Madjid (Jakarta: Kompas, 2001), h. xxxviii-ix; Sukidi, "Ketika Kebenaran Ditafsirkan," dalam Jawa Pos (11 Januari 2004). Dalam artikel ini Sukidi menggunakan tamsil pohon yang memiliki banyak cabang tetapi tetap berasal dari akar yang sama.

${ }^{21}$ Mun'im A Sirry, "Pluralisme Agama," dalam Majalah Ummat (1 Maret 1999/13 Dzulkaidah 1419), h. 90; Lihat juga Hidayat, "Membangun Teologi Dialogis dan Inklusivistik," h. 45; Hidayat dan Nafis, Agama Masa Depan, h. 69. 
Bukan Tuhan pada dirinya sendiri. Tetapi lebih sebagai Tuhan yang dikonstruk oleh manusia sesuai dengan kemampuan persepsi, penangkapan, dan pengetahuannya. Tuhan model ini, lanjutnya, merupakan Tuhan yang bertempat dalam ide, pemikiran, gagasan, atau konsep yang diikat dengan kepercayaan manusia. ${ }^{22}$

Karena itu, dengan mengutip pendapat Ibnu 'Arabi, Hidayat dan Nafis menyatakan bahwa Tuhan sebagai Zat Yang Absolut sebenarnya tidak butuh nama. Bila Tuhan diberi nama, maka tidak ada sebuah nama pun yang tepat. Karena jika Yang Absolut itu dapat didefinisikan, berarti Tuhan sudah tidak absolut lagi. Hal ini karena definisi merupakan penciutan dan pembatasan (reduksi) terhadap sebuah realitas. ${ }^{23}$ Konsep Tuhan kepercayaan yang berbeda dengan Tuhan dalam dirinya sendiri ini mengingatkan pada pembedaan John Hick antara Tuhan dalam diri-Nya sendiri (the Real an sich) dan Tuhan dalam pemikiran dan pengalaman manusia (the Real as humanly experienced and thought).

Ulil Abshar Abdalla melangkah lebih jauh dengan pendapat bahwa konsekuensi logis dari kebersatuan agama-agama dalam aspek esoterisme tersebut adalah adanya tuntutan bagi setiap pemeluk agama untuk menanggalkan klaim kebenaran absolutnya dan digantikan dengan klaim kebenaran absolut yang relatif (relatively absolute truth claim). Menurut Abdalla, kebenaran mutlak setiap agama hanya berlaku bagi pemeluknya dan tidak berlaku bagi pemeluk agama lain. Abdalla menjelaskan, perbedaan persepsi tentang Tuhan dalam bentuk agama-agama di aspek eksoterik itu harus diberikan tempat dengan pengelolaan yang baik sehingga melahirkan mutual enrichment (saling memperkaya), bukan berkonflik. Di sini Abdalla mengibaratkannya sebagai pasar di mana agama-agama adalah kios-kios yang menyajikan berbagai macam 'dagangan kebenaran' sesuai bentuk persepsi masing-masing pedagang dalam rangka berkompetisi dalam kebaikan. ${ }^{24}$ Dalam kacamata esoterisme eksoterisme, perbedaan yang tampak pada agama-agama yang ada sesungguhnya hanya terlihat pada aspek eksoterismenya saja, tidak pada aspek substansi kebenarannya (esoterik). Secara syariat memang ada perbedaan di setiap agama, namun semua itu bertemu dalam satu titik kesatuan kebenaran yang tunggal dan universal. Dalam terminologi Islam hal itu disebut sebagai tauhid.

Menurut Nurcholish Madjid, tauhid merupakan ajaran untuk tunduk, pasrah, dan patuh hanya kepada Tuhan Yang Maha Esa (Allah), tanpa membuka peluang untuk melakukan hal serupa kepada selain-Nya (thâghût). Ini ditegaskan dalam beberapa ayat, "Dan Kami tidak mengutus seorang Rasul pun sebelum kamu, melainkan Kami wahyukan kepadanya: Bahwasanya tidak ada Tuhan (yang hak) melainkan Aku, maka sembahlah olehmu sekalian

\footnotetext{
${ }^{22}$ Kautsar Azhari Noer, "Tuhan Kepercayaan," dalam Luthfie Assyaukanie (ed.), Wajah Liberal Islam di Indonesia (Jakarta: JIL dan TUK, 2002), h. 69

${ }^{23}$ Hidayat dan Nafis, Agama Masa Depan, h. 80

${ }^{24}$ Abdalla, "Keragaman dalam Pandangan Islam," dalam M. Imdadun Rahmat, et al., Islam Pribumi: Mendialogkan Agama, Membaca Realitas (Jakarta: Erlangga, 2003), h. 115-119.
} 
akan Aku'." "Dan sesungguhnya Kami telah mengutus rasul pada tiap-tiap umat (untuk menyerukan): 'Sembahlah Allah (saja), dan jauhilah thâghût itu'. Maka di antara umat itu ada orang-orang yang diberi petunjuk oleh Allah dan ada pula di antaranya orang-orang yang telah pasti kesesatan baginya. Maka berjalanlah kamu di muka bumi dan perhatikanlah bagaimana kesudahan orang-orang yang mendustakan (Rasul-rasul)."26

Ajaran ini (tauhid) merupakan inti dari risalah yang diemban oleh tiap-tiap nabi dan rasul di setiap komunitas yang berbeda, dan tentunya, termuat dalam kitab-kitab suci yang mereka bawa. Di sini Madjid membedakan antara "Islam" dengan huruf "I" besar dengan "islam" dengan "i” kecil. Konsep "islam" (dengan "i” kecil) digunakan untuk menyebut "islam" sebagai sikap ketundukan kepada Tuhan atau "islam" dalam maknanya yang generik. Sedangkan kata "Islam" dengan "I" besar digunakan untuk menyebut Islam sebagai nama keyakinan yang dipeluk oleh umat Nabi Muhammad. ${ }^{27}$ "islam" dengan "i" kecil inilah yang disebut Madjid sebagai "al-islâm", yaitu aktivitas kepasrahan total kepada Yang Tunggal. Di sini, "islam" tidak dipahami secara eksklusif sebagai identitas (nama) risalah yang dibawa Nabi Muhammad, namun merujuk pada maknanya yang umum (generik) sebagai sebuah sikap kepasrahan dan ke-berserahdiri-an hanya kepada-Nya. ${ }^{28}$

Madjid menjelaskan, sikap ber-islâm itu merupakan misi sejati setiap nabi dan rasul. Sekaligus menjadi risalah agama-agama mereka sebagaimana yang dimaksud dalam surah al-Anbiya'/21: 25 di atas. Setiap agama pasti mengandungi sikap pasrah, tegas Madjid. Tanpa kepasrahan suatu agama menjadi tidak murni dan harus ditolak. Di sini Madjid mengutip firman Allah: "Sesungguhnya agama di sisi Allah adalah 'al-islâm", dan "barang siapa menganut agama selain 'al-islâm' (sikap pasrah) maka tidak akan diterima dari padanya, dan di akhirat dia termasuk mereka yang menyesal." ${ }^{29}$ Karenanya, dengan mengutip pendapat Abdullah Yusuf Ali, Madjid menyimpulkan bahwa Islam bukanlah agama yang ditujukan untuk orang Muslim saja. Islam bukan sebuah sekte atau agama etnis. Islam merupakan ajaran ketundukan hanya kepada Yang Mutlak. Agama yang inklusif dan universal tanpa pembatasan identitas komunal. Islam, jelasnya, memandang semua agama sama karena sesungguhnya kebenaran adalah satu. ${ }^{30}$

${ }^{25}$ Q.S. al-Anbiyâ'/21: 25.

${ }^{26}$ Q.S. al-Nahl/16: 36.

${ }^{27}$ Nurcholish Madjid, Islam: Doktrin dan Peradaban (Jakarta: Paramadina, 1992), h. 180181; Mun'im A Sirry (ed.), Fiqh Lintas Agama: Membangun Masyarakat Inklusif-Pluralis (Jakarta: Paramadina, 2004), h. 18-20; Komaruddin Hidayat dan Wahyuni Nafis, Agama Masa Depan, h. 58-59; Lihat juga Abd. Moqsith Ghozali, "Cetak Biru Toleransi di Indonesia," dalam Jawa Pos (6 Oktober 2002).

${ }^{28}$ Ibid.

${ }^{29}$ Q.S. Âli 'Imrân/3: 19 dan 85.

${ }^{30}$ Madjid, Islam Doktrin, h. 182- 185; Lihat juga Ulil Abshar Abdalla, Menjadi Muslim Liberal (Jakarta: Nalar, 2005), h. 9-10. Nurcholish Madjid membangun gagasan inklusivisme-nya ini dengan merujuk pada pemikiran Ibn Taimiyah. Namun setelah diteliti, penyandaran ide inklusivisme pada Ibn Taimiyah yang dilakukan oleh Madjid tidak tepat, lihat S. Mahmudah Noorhayati dan 
Para penganjur teologi pluralisme agama menegaskan bahwa keimanan pemeluk agama samawi (Yahudi, Nasrani, atau Islam) dan pemeluk agama-agama lainnya akan diterima oleh Allah jika didasarkan pada kepasrahan dan terbebas dari sekat-sekat sektarianisme dan komunalisme (Q.S. al-Baqarah/2: 62 dan 112). Menurut mereka, komunalisme dan sektarianisme beragama di kalangan Yahudi dan Nasrani digambarkan oleh al-Qur'an sebagai omong kosong tanpa argumentasi (Q.S. al-Baqarah/2: 111), sehingga Allah menolak klaim yang menyebutkan Nabi Ibrahim sebagai bagian dari Yahudi atau Nasrani karena sesungguhnya ia adalah seorang hanaîf yang muslim (Q.S. Âli 'Imrân/3: 67).

Dalam pandangan mereka perkataan $\underline{h} a n \hat{\imath} f$ merujuk pada yang murni, suci dengan berinti pada pandangan tauhid. Sementara muslim merujuk pada totalitas ketundukan dan kepasrahan hanya kepada Tuhan Yang Maha Esa (islâm). Ini berarti ajaran kehanîf-an dan kemusliman Ibrahim merupakan keberagamaan yang terbebas dari sikap komunalisme, berbeda dari komunitas Yahudi dan Nasrani. ${ }^{31}$ Lebih lanjut dinyatakan bahwa kesatuan kebenaran dalam agama-agama tersebut sesungguhnya telah ditegaskan oleh posisi al-Qur'an yang hadir untuk mengakui kebenaran kitab-kitab sebelumnya (Q.S. al-Mâ’idah/5: 48 dan Q.S. Yûnus/10: 37). Artinya, simpul mereka, kehadiran Islam bukanlah untuk membatalkan agama-agama sebelumnya, melainkan untuk mengakui kebenaran misi agama-agama itu.

Menurut Madjid, risalah yang dibawa Muhammad adalah kontinuitas (kelanjutan) dari dan merupakan satu kesatuan dari kenabian. Risalah itulah yang di kemudian hari menjadi proper name agama umatnya, Islam (Q.S. al-Syûrâ/42: 13). Karena itulah, Nabi Muhammad SAW. datang tidak dengan membawa ajaran baru. Kehadirannya di dunia ini sekadar untuk melengkapi sebuah bangunan besar kenabian. Dalam sebuah hadis, jelas Madjid, kenabian diibaratkan sebagai sebuah bangunan besar yang indah dan bagus. Namun di dalamnya terdapat satu tempat ubin yang belum terisi. Banyak orang yang tertegun melihat bangunan tersebut kemudian bertanya: "Kenapa ubin itu tidak dipasang?." Nabi pun menjawab, "Saya lah ubin itu, aku merupakan penutup para nabi." Karenanya umat Islam dituntut oleh al-Qur'an untuk mengimani para nabi dan kitab-kitab sebelum Muhammad tanpa membeda-bedakannya (Q.S. al-Baqarah/2: 136; Q.S. al-Nisâ'/4: 163).

Islam memang mengklaim sebagai agama terakhir yang memuncaki proses pertumbuhan dan perkembangan agama-agama dalam garis kontinuitas kenabian tersebut. Namun Madjid menegaskan, justru Islam mengakui hak agama-agama itu untuk eksis dan tetap dilaksanakan. Islam bukan ajaran supersessionisme yang memposisikan agama yang datang belakangan sebagai pengganti agama-agama sebelumnya. ${ }^{32}$

Ahmad Khoirul Fata, "Exclusive Islam From the Perspective of Ibn Taymiyah," dalam Esensia, Vol. 18, No. 2, 2017, h. 213-224.

${ }^{31}$ Sirry (ed.), Fiqih Lintas Agama, h. 26-27.

${ }^{32}$ Nurcholish Madjid, Islam Doktrin, h. lxxviii. Lihat juga Nurcholish Majid, "Keluarga Imran, Siti Mayam, dan Isa al-Masih," dan Komaruddin Hidayat, "Membangun Teologi Dialogis dan 


\section{Kontroversi Teologi Pluralisme Agama}

Teologi pluralisme agama mendapat reaksi keras dari berbagai kelompok umat Islam di Indonesia. Di kalangan ormas Islam mainstream muncul kelompok-kelompok yang kontra dengan gagasan-gagasan pluralisme dan liberalisme. Majelis Tarjih PP Muhammadiyah berupaya membendung gejala munculnya gagasan liberalisme dan pluralisme dengan berbagai kegiatan dan penerbitan berkala. Tidak kalah dengan itu para kiai Nahdlatul Ulama (NU) juga menentangnya melalui Bassra (Badan Silaturrahim Ulama Madura). Selain itu juga muncul kelompok NU Garis Lurus yang bersuara kencang menentang paham-paham yang dinilai bertentangan dengan ajaran Ahl al-Sunnah wa al-Jamâ'ah (Aswaja) NU, di antaranya paham pluralisme dan liberalisme.

Selain menuai reaksi dari ormas-ormas Islam mainstream, liberalisme juga mendapat tentangan dari kaum cendekiawan. Sekelompok cendekiawan muda yang kebanyakan lulusan dari Malaysia berkumpul dan membentuk lembaga INSISTS (Institute for the Study of Islamic Thought and Civilization) dengan agenda utama membendung arus gagasan liberal itu. Kelompok ini tercatat aktif memproduksi wacana tandingan terhadap ide-ide liberalisasi agama dengan menerbitkan tulisan, jurnal, dan menggelar diskusi-diskusi ilmiah. Mereka bahkan membuat jaringan-jaringan keilmuan di beberapa daerah untuk kebutuhan tersebut. $^{33}$

Kontroversi itu kemudian menjadi booming saat Majelis Ulama Indonesia (MUI) mengeluarkan fatwa keharaman paham pluralisme, liberalisme dan sekularisme pada 2005. MUI menfatwakan bahwa ketiga paham tersebut tidak sesuai dengan ajaran Islam. MUI juga mengharamkan umat Islam mengikuti ketiga paham tersebut. Lebih jauh lagi MUI juga mengeluarkan beberapa fatwa yang merupakan turunan dari fatwa tersebut, seperti keharaman doa bersama atau pernikahan lintas agama, pembagian waris dalam keluarga yang berbeda agama, dan larangan perempuan menjadi imam salat jamaah.

Dalam fatwanya MUI menjelaskan bahwa pluralisme agama merupakan keyakinan "bahwa semua agama sama dan kebenaran setiap agama adalah relatif; setiap pemeluk agama tidak boleh mengklaim hanya agamanya yang benar, agama yang lain salah; semua pemeluk agama akan masuk dan hidup berdampingan di surga." Terminologi ini berbeda dengan kata "pluralitas" yang berarti kenyataan adanya berbagai pemeluk agama berbeda yang hidup secara berdampingan. Sedangkan sekularisme dimaknai oleh MUI sebagai pemisahan urusan dunia dari agama. Bagi kaum sekularis, agama hanya berfungsi untuk mengatur urusan privat (hubungan pribadi dengan Tuhan). Sedangkan relasi sosial diatur melalui

Inklusivistik," dalam Komaruddin Hidayat dan Ahmad Gaus AF (ed.), Passing Over: Melintasi Batas Agama (Jakarta: Gramedia, 2001), h. 386-387 dan 39-40. Hadis tersebut diriwayatkan oleh Imam Muslim dan termaktub dalam Shahih ㅆ Muslim, Kitâb Fadhâ'il, Bâb Zikr Kawnihi Khatam al-Anbiyâ.'

${ }^{33}$ Lihat Ahmad Khoirul Fata, "INSISTS dan Gerakan Anti Liberalisme di Indonesia," dalam Jurnal Kajian dan Pengembangan Manajemen Dakwah, Vol. 04, No. 01, 2014, h. 65-82 
kesepakatan sosial. Sementara liberalisme dimaknai oleh MUI sebagai paham yang memahami nash agama dengan memakai akal pikiran secara bebas atau hanya menerima doktrin agama yang dianggap sesuai dengan akal pikiran.

Meski pihak penyokong gagasan pluralisme agama menolak definisi versi MUI tersebut, namun tak pelak fatwa MUI itu menjadikan wacana pluralisme agama terdorong ke belakang dengan munculnya sinisme dan ketakutan di kalangan umat Islam. Gagasan pluralisme agama secara substansial memang kontroversial karena bernuansa "menyamaratakan" kebenaran agama-agama. Dilihat dari perspektif tiga tahap perkembangan cara beragama di atas (eksklusivisme, inlusivisme, dan pluralisme), kesan dan nuansa tersebut sangat terasa dalam gagasan pluralisme agama. Bagaimana pun juga, klaim kebenaran mutlak tidak bisa dihapuskan dari doktrin dan keyakinan keagamaan. Ini terkait erat dengan kenyataan bahwa agama merupakan keyakinan pada kebenaran yang bersumber langsung dari Yang Maha Benar. Kebenaran agama selalu diyakini lintas waktu dan tempat sehingga mengharuskan keyakinan yang sepenuhnya. Keyakinan itu semakin diperkuat dengan janji keselamatan bagi yang mengakuinya.

Dalam Islam sendiri, keyakinan mutlak pada kebenaran Islam sangat terasa dalam berbagai nash, di antaranya: "sesungguhnya agama di sisi Allah adalah al-islâm,"34 dan "Barang siapa menganut agama selain Islam, maka tidak akan diterima daripadanya, dan di akhirat dia termasuk mereka yang menyesal." ${ }^{35}$ Namun para penyokong pluralisme agama mencoba memberi tafsir baru terhadap ayat-ayat tersebut. Menurut mereka kata "Islâm" dalam ayat tersebut bermakna generik bukan proper name agama tertentu. Menurut Nurcholish Madjid, kata "al-Islâm" pada ayat tersebut tidak memiliki makna eksklusif sebagai nama sebuah agama yang dibawa Nabi Muhammad, tetapi merujuk pada makna generalnya sebagai sikap penuh kepasrahan dan berserah diri hanya kepada-Nya. ${ }^{36}$ Meski demikian, penafsiran model ini tetap ditolak banyak pihak. Bahkan semakin memperkuat tuduhan kalangan ulama bahwa pluralisme agama merupakan paralelisme agama-agama.

Jika benar paham pluralisme agama memang bermakna pengakuan adanya kebenaran dalam setiap tradisi agama-agama dan kepercayaan yang ada, maka tentu saja paham ini sangat dilematis bagi umat beragama, khususnya umat Islam, dan pantas mendapat banyak penolakan. Menurut Muhammad Legenheusen, ${ }^{37}$ minimal ada tujuh hal yang dilematis dalam gagasan tersebut, yaitu kenyataan bahwa dalam suatu agama terdapat keragaman budaya; dalam suatu kebudayaan terdapat keragaman agama; adanya fenomena konversi (perpindahan) agama; adanya klaim kebenaran universal dalam setiap agama; dalam setiap agama ada ajaran dakwah atau missi yang bertujuan mengajak orang luar

${ }^{34}$ Q.S. Âlî 'Imrân/3: 19.

${ }^{35}$ Q.S. Âlî 'Imrân/3: 85.

${ }^{36}$ Lihat Madjid, Islam Doktrin, h. 180-181.

${ }^{37}$ Muhammad Legenhausen, Satu Agama atau Banyak Agama: Kajian Tentang Liberalisme dan Pluralisme Agama, terj. Arif Mulyadi (Jakarta: Lentera, 1999), h. 146. 
untuk menganut suatu agama tertentu; adanya kontradiksi doktrinal di antara agamaagama yang ada di dunia ini; dan adanya kontradiksi ritual praktis dalam setiap agama.

Kenyataan bahwa gagasan pluralisme agama begitu kontroversial mengharuskan suatu upaya untuk mengevaluasi kembali penyebaran gagasan tersebut ke tengah-tengah masyarakat. Jika terus menerus memaksa penyebarannya, sementara "pasar" jelas-jelas tidak menerima, hal itu hanya akan menjadi perbuatan sia-sia dan justru menghadirkan arus perlawanan yang lebih keras lagi. Karenanya kajian kritis dan mendalam terhadap gagasan tersebut perlu dilakukan. Hal fundamental yang harus dikaji dari gagasan pluralisme agama adalah anggapan bahwa eksklusivisme beragama menjadi sumber konflik dan kekerasan sosial perlu dikaji secara kritis.

Kajian Tim Institut Titian Perdamaian menunjukkan data terjadinya kasus konflik dan kekerasan pada periode 2008-2010 sebanyak 4.021. Dari sejumlah itu konflik bernuansa agama (penyerangan terhadap kelompok minoritas atau perusakan tempat ibadah) terjadi sebanyak 90 kasus (2,2\%), politik 559 kasus (13,9\%), konflik antar aparat negara 31 kasus (0,8\%), konflik sumber daya alam 313 kasus (7,8\%), konflik sumberdaya ekonomi 332 kasus (8,3\%), tawuran antar kelompok masyarakat 1.089 kasus $(27,1 \%)$, penghakiman massa 1.107 kasus (27,5\%), pengeroyokan 302 kasus (7,5\%), dan lain-lain sebanyak 198 kasus $(4,9 \%) \cdot{ }^{38}$

Data tersebut menunjukkan betapa kasus kekerasan atas nama agama tidak menempati posisi penting dalam kasus-kasus kekerasan yang terjadi sepanjang tahun-tahun tersebut. Meskipun demikian, jika ditelisik lebih mendalam, banyak kasus konflik dan kekerasan agama yang ada sesungguhnya tidak murni bersumber dari perbedaan doktrin dan paham agama. Faktor-faktor sosiol, ekonomi, politik, dan etnik sangat mungkin lebih dominan sebagai pemicu dari pada faktor agama itu sendiri.

Sebagai contoh kasus konflik yang terjadi di Sambas dan Ambon yang saling berlindan antar berbagai faktor. Riset yang dilakukan Masdar Hilmy dan kawan-kawannya menyimpulkan bahwa konflik di dua daerah tersebut terjadi dengan melibatkan banyak faktor, di antaranya: kesenjangan ekonomi, diskriminasi politik, separatisme, adanya pihak ketiga (provokator) dan runtuhnya kewibawaan hukum yang bertumpang tindih dengan faktor perbedaan budaya dan agama. ${ }^{39}$ Sebab itu, menuduh perbedaan agama sebagai faktor tunggal atau faktor utama dalam kasus-kasus konflik bernuansa agama bisa menyesatkan. Ketidaktepatan dalam mengenali faktor-faktor penyebab konflik bisa mengakibatkan kesalahan dalam membuat resolusi konflik. Alih-alih menyelesaikan masalah, kekeliruan itu justru bisa menjadi pemicu konflik yang semakin lebar dan besar.

\footnotetext{
${ }^{38}$ Tim Penulis Institut Titian Perdamaian, Dinamika Konflik dan Kekerasan di Indonesia (Jakarta: Institut Titian Perdamaian, 2011), h. 10 dan 14.

${ }^{39}$ Lihat Masdar Hilmy, et al., "Membedah Anatomi Konflik Agama-Etnik: Rekonstruksi Paradigma Teori dan Resolusi Konflik Agama-Etnik Pasca Orde Baru" (Penelitian, Kementerian Riset dan Teknologi dan Lembaga Ilmu Pengetahuan Indonesia, 2004).
} 
Meskipun demikian, secara logis bisa dinalar, seandainya memang benar bahwa perbedaan agama-agama dengan masing-masing klaim kebenarannya menjadi faktor penentu konflik sosial, kenapa konflik-konflik yang terjadi hanya di beberapa bagian daerah tertentu? Kenapa tidak terjadi merata di seluruh wilayah Indonesia? Bukankah di setiap bagian wilayah NKRI terdapat umat beragama yang berbeda? Kenyataannya, konflik hanya terjadi di wilayah-wilayah tertentu yang memang secara historis memiliki "problem" sosial, ekonomi, atau pun politik. Karena itulah, menuduh agama sebagai faktor utama terjadinya konflik sosial sesungguhnya sebuah sikap yang tergesa-gesa dan reduktif.

\section{Beragama Secara Eksklusif-Toleran}

Islam pada dasarnya memiliki dua sisi: inklusif dan eksklusif. Inklusivitas Islam terletak pada hakikat dirinya sebagai agama para nabi dan rasul yang berinti pada ajaran tauhid. Ini adalah Islam dalam makna generiknya. Pada makna ini sesungguhnya Islam adalah agama sepanjang sejarah manusia. Para nabi dan rasul datang dan diutus oleh Tuhan dengan membawa risalah yang mengajarkan penyembahan dan ketundukan (islâm) hanya kepada Tuhan Yang Maha Esa tanpa menyekutukan-Nya dengan sesuatu apapun (tauhîid) (lihat Q.S. al-Nahl/16: 36). Islam model ini adalah agamanya para nabi seperti Nabi Nuh (Q.S. Yûnus/10: 71-72), Nabi Ibrahim (Q.S. al-ㅌajj/22:78; Âli 'Imrân/3:67), Nabi Ya'qûb (Q.S. al-Baqarah/2: 132), Nabi Yûsuf (Q.S. Yûsuf/12: 101), Nabi Sulaiman (Q.S. al-Naml/27: 29-31), Nabi Musa (Q.S. al-A'râf/7: 126, Yûnus/10: 84), dan Nabi 'Isa (Q.S. Âli 'Imrân/3:52).

Islam seperti ini adalah agama semua utusan Allah dan agama semua umat manusia. Karena Tuhan sudah mengutus utusan-utusan-Nya kepada setiap kelompok manusia demi keadilan (Lihat Q.S. al-Isrâ'/17:15, Q.S. al-Nahl/16: 36, Q.S. al-Mu'minûn/23: 44). Semua utusan Tuhan tersebut dipertemukan pada satu risalah yang sama, yaitu tauhid. Misi ini tidak akan pernah berubah karena ia adalah fithrah (Q.S. al-Rûm/30: 30). Inilah pondasi dasar keimanan Islam. Setiap orang beriman diharuskan meyakini semua utusan Allah (nabi dan rasul) dan apa yang ada pada mereka (wahyu atau kitab suci). Mengingkari sebagian dan meyakini sebagian dari mereka adalah tanda ketidakberimanan (lihat Q.S. al-Baqarah/2: 136, 137, 285; Q.S. Âli Imrân/3: 84; dan Q.S. al-Mâ'idah/4: 163). AlQur'an sebagai bagian dari rentetan wahyu-wahyu Tuhan datang untuk meneguhkan risalah para nabi dan rasul sebelumnya (Q.S. Âli Imrân/3: 2-3).

Bila pada dasarnya agama yang dibawa para utusan Tuhan untuk umat manusia adalah sama, kenapa terjadi perbedaan agama di tengah-tengah masyarakat? Ada dua sebab terjadinya keragaman agama-agama. Pertama, meski membawa risalah yang sama, namun setiap nabi datang dalam konteks kesejarahan masing-masing. Nabi-nabi datang kepada masyarakatnya dengan ajaran inti tauhid, namun di saat yang sama, juga mengajarkan cara atau aturan bertauhid tersebut sesuai dengan partikularitas konteks ruang waktunya masing-masing. Kedua, wahyu Tuhan yang dibawa para utusan (nabi/rasul) 
dengan satu misi utama (tauhid) ternyata tidak ditangkap secara sama dan baik oleh masyarakat yang bersangkutan. Terdapat banyak faktor yang menjadikan perbedaan pemahaman atas wahyu tersebut, baik faktor internal (dari diri pribadi yang bersangkutan) atau faktor eksternal seperti status sosial, ekonomi dan politik. Faktor perjalanan waktu turut berpengaruh dalam memudarkan pemahaman dan praktik kandungan wahyu tersebut di tengah-tengah masyarakat. ${ }^{40}$

Di sinilah maksud Tuhan menghadirkan utusan-utusan lain di kemudian hari adalah untuk me-refresh misi utama utusan-utusan sebelumnya (tauhid) yang telah lekang dimakan sejarah. Tentu saja utusan yang hadir kemudian itu datang dengan aturan-aturan baru yang- seringkali-berbeda dengan aturan yang dibawa utusan sebelumnya agar ada ketersambungan dengan realita historis yang baru. Ini artinya, kehadiran utusan yang terkemudian adalah tanda bagi ketidakberlakuan aturan-aturan partikular yang diajarkan utusan-utusan sebelumnya. Kecuali ada konfirmasi ulang atas validitas aturan lama tersebut oleh aturan yang dibawa utusan yang baru. Puncak rentetan dari para utusan tersebut adalah Nabi Muhammad yang disebut sebagai mata rantai terakhir para nabi (Lihat Q.S. al-Ahzâb/33: 40). Dengan demikian, aturan-aturan baru yang dibawa Nabi Muhammad adalah abadi hingga akhir sejarah dan berlaku untuk semua umat manusia tanpa melihat warna kulit dan identitas komunalnya mengingat ketiadaan utusan setelah Muhammad (Q.S. al-Zumar/39: 41; Q.S. al-'Anbiyâ'/21:107; Q.S. Sabâ'/34: 28).

Sementara itu, kehadiran Nabi Muhammad dengan wahyu al-Qur'an memiliki dua fungsi. Pertama, untuk meneguhkan kembali kebenaran risalah utusan-utusan sebelumnya yang terkandung dalam kitab suci masing-masing. Kedua, sebagai penguji bagi kitabkitab tersebut, untuk meluruskan penyimpangan dan kekeliruan yang ada padanya, dan menghilangkan kebatilan dan takwil keliru yang menimpa kitab-kitab suci tersebut (Q.S. al-Mâ'idah/5: 48). ${ }^{41}$ Aturan baru yang dibawa Nabi Muhammad membuat seluruh aturan yang dibawa para utusan sebelumnya tidak berlaku lagi (kecuali ada konfirmasi validitas dari aturan baru), dan konsekuensinya, semua kelompok-kelompok manusia yang dahulu pernah mengikuti aturan para utusan sebelum Nabi Muhammad mesti mengikuti aturan baru yang dibawa beliau dan meninggalkan aturan lama itu (Q.S. alMâ'idah/5: 15, 19, 48, 68; Q.S. al-Nisâ'/4: 47; dan Q.S. al-Nahll/16: 63-64).

Keengganan mengakui konsekuensi ini dapat menghilangkan jaminan keselamatan (salvation) dari Tuhan karena mereka dianggap hanya beriman kepada sebagian utusan dan sebagian kitab yang dibawanya (Q.S. al-Baqarah/2: 136-137, 285; Q.S. Âli 'Imrân/ 3: 3-4, 20). Orang tersebut telah mengingkari perjanjian dengan Allah yang mewajibkan mereka beriman dan menolong Nabi Muhammad (Q.S. Âli ‘Imrân/3: 81-82). Sebaliknya,

\footnotetext{
${ }^{40}$ Ismail Raji al-Faruqi dan Lois Lamya al-Faruqi, the Cultural Atlas of Islam (New York: MacMillan Publishing Company dan London: Collier MacMillan Publishers, 1986), h. 193.

${ }^{41}$ Yûsuf Qardhâwî, Islam Inklusif dan Eksklusif, terj. Nabhani Idris (Jakarta: Pustaka al-Kautsar, 2001), h. 48-49.
} 
siapa saja di antara mereka yang mengikuti Nabi Muhammad, mereka tetap mendapatkan jaminan tersebut (Q.S. Âli 'Imrân/3: 199; Q.S. al-Ra'd/13: 38). Bahkan mereka akan mendapatkan balasan berlipat (Q.S. al-Qashshash/28: 52-54). Langkah salah dengan menolak keimanan kepada Nabi Muhammad dan yang dibawanya (al-Qur'an) telah dilakukan sebagian orang yang mengaku sebagai pengikut Nabi Musa (kaum Yahudi) dan Nabi Isa (Nasrani) (Q.S. al-Baqarah/2: 87-91; al-Ankabût/29: 47). Mereka sebenarnya mengetahui kewajiban tersebut karena informasi tentang kedatangan al-Qur'an dan Nabi Muhammad telah termaktub dalam kitab-kitab mereka (Q.S. al-Syu'arâ/26: 196; Q.S. al-Shaff/61: 6), namun dengan berbagai motif mereka pun mengingkarinya (Q.S. al-Baqarah/2: 146; Q.S. al-An'âm/6: 114).

Di sinilah letak sisi eksklusivitas dan keunggulan Islam yang dibawa Nabi Muhammad atas Islam-islam yang dibawa para rasul sebelumnya. Klaimnya sebagai penutup dan pengganti aturan-aturan kenabian sebelumnya secara tidak langsung menyatakan bahwa Islam yang dibawa Nabi Muhammad lah satu-satunya jalan yang absah untuk mengabdi kepada Tuhan Yang Maha Esa (al-islâm). Aturan-aturan lain sudah dianggap tidak layak lagi menjadi jalan bertauhid, dan karenanya, menyesatkan. Karena itu wajar bila Nabi Muhammad mengatakan kepada 'Umar bin al-Khaththâb yang sedang memegang Kitab Taurat: "seumpama saudaraku Musa masih hidup di zamanku, tentu dia tidak akan keberatan mengikutiku" (H.R. Bukhârî dan Bazzar). Islam yang eksklusif tersebut dibangun di atas lima pondasi utama, yaitu: kesaksian pada tauhid dan kerasulan Muhammad, salat, zakat, puasa dan haji ke Baitullâh di Makkah bila ada kemampuan untuk itu. Dalam beberapa hadis Nabi Muhammad menjanjikan siapa pun yang mendirikan bangunan tersebut secara konsisten akan mendapatkan pahala di sisi Tuhan. ${ }^{42}$

Dengan demikian, bila dilihat dalam perspektif John Hick tentang tiga sikap beragama (eksklusif, inklusif dan pluralis) sebagaimana yang dipaparkan di atas, Islam yang dibawa Nabi Muhammad dengan klaim kebenaran mutlaknya dapat dikategorikan sebagai agama yang eksklusif. Apakah eksklusivisme Islam tidak mengundang terjadinya kekerasan dan konflik sosial? Meskipun Islam bersifat eksklusif, dan dalam beberapa kasus keberagamaan yang eksklusif bisa mendorong perilaku agresif, namun Islam sudah mengantisipasi potensi tersebut agar tidak tumbuh menjadi liar. Ini terlihat dari berbagai teks al-Qur'an, seperti larangan tegas mencaci-maki tuhan-tuhan agama lain selain Allah. Seperti termaktub dalam ayat: "Dan janganlah kamu memaki sembahan-sembahan yang mereka sembah selain Allah, karena mereka nanti akan memaki Allah dengan melampaui batas tanpa pengetahuan. Demikianlah Kami jadikan setiap umat menganggap baik pekerjaan mereka." ${ }^{43}$ Jika dalam hal remeh-temeh seperti mencaci saja dilarang oleh Islam, apalagi dalam hal yang besar seperti berperang. Nash al-Qur'an secara tegas melarang umat Islam memerangi umat

\footnotetext{
${ }^{42}$ Lihat Imam Muslim, Shaĥîh Muslim, Juz I (Beirut: Dâr al-Kutub al-'Ilmiyyah, 1992), terutama bagian Kitâb Îmân.

${ }^{43}$ Q.S. al-An'âm/6: 108.
} 
lain kecuali mereka yang terlebih dahulu melakukannya. "Dan perangilah di jalan Allah orang-orangyang memerangi kamu. Janganlah kamu melampaui batas. Karena sesungguhnya Allah tidak menyukai orang-orang yang melampaui batas." ${ }^{44}$

Lebih lanjut, dalam kehidupan sosial seringkali terjadi diskusi dan perdebatan di antara umat beragama. Namun demikian, al-Qur'an juga dengan tegas mewajibkan umat Islam untuk melakukan diskusi dan perdebatan tersebut dengan jalan yang sebaik-baiknya. "Serulah (manusia) kepada jalan Tuhan-mu dengan hikmah dan pelajaran yang baik dan bantahlah mereka dengan carayang baik. Sesungguhnya Tuhanmu Dialahyang lebih mengetahui tentang siapa yang tersesat dari jalan-Nya. Dan Dialah yang lebih mengetahui orang-orang yang mendapat petunjuk." 45

Dalam perdebatan dan dialog itu Islam menyuruh umatnya untuk mengajak mereka menuju ke satu kesepakatan untuk mengakui keesaan Tuhan. "Katakanlah: 'Hai ahli Kitab, marilah (berpegang) kepada suatu kalimat (ketetapan) yang tidak ada perselisihan antara Kami dan kamu, bahwa tidak kita sembah kecuali Allah dan tidak kita persekutukan Dia dengan sesuatupun dan tidak (pula) sebagian kita menjadikan sebagian yang lain sebagai Tuhan selain Allah.' Jika mereka berpaling maka katakanlah kepada mereka: 'Saksikanlah, bahwa kami adalah orang-orang yang berserah diri (kepada Allah)'."46

Namun bila perdebatan tersebut tidak menghasilkan kata sepakat, umat Islam diharuskan mengembalikan persoalan tersebut kepada Allah dan menghindari ketegangan lebih lanjut. "Maka karena itu serulah (mereka kepada agama ini) dan tetaplah sebagaimana diperintahkan kepadamu. Dan janganlah mengikuti hawa nafsu mereka dan katakanlah: Aku beriman kepada semua kitab yang diturunkan Allah dan aku diperintahkan supaya berlaku adil di antara kamu. Allah-lah Tuhan kami dan Tuhan kamu. Bagi kami amal-amal kami dan bagi kamu amal-amal kamu. Tidak ada pertengkaran antara kami dan kamu. Allah mengumpulkan antara kita dan kepada-Nyalah kembali (kita)'."47

Umat Islam juga dilarang memaksa mereka untuk memeluk Islam. Meskipun Islam adalah agama yang paling benar. "Tidak ada paksaan dalam agama. Sesungguhnya telah jelas jalan yang benar daripada jalan yang sesat. Karena itu barangsiapa yang ingkar kepada thâghût dan beriman kepada Allah, maka sesungguhnya ia telah berpegang kepada tali yang amat kuat yang tidak akan putus. Dan Allah Maha Mendengar lagi Maha Mengetahui." $" 48$

Ayat-ayat yang memberikan panduan bagaimana berinteraksi dengan orang nonMuslim tersebut secara nyata menunjukkan betapa toleransi Islam terhadap perbedaan

\footnotetext{
${ }^{44}$ Q.S. al-Baqarah/2: 190.

${ }^{45}$ Q.S. al-Nahl/16: 125 .

${ }^{46}$ Q.S. Âli 'Imrân/3: 64.

${ }^{47}$ Q.S. al-Syûrâ/42: 15.

${ }^{48}$ Q.S. al-Baqarah/2: 256.
} 
agama. Dapat disimpulkan bahwa Islam adalah agama yang eksklusif. Namun di sini perlu ditambahi dengan penjelasan bahwa eksklusivisme Islam adalah eksklusivisme yang toleran terhadap keberadaan agama-agama lainnya. Agama-agama yang berbeda itu diakui oleh Islam sebagai realitas sosial. Toleransi Islam bukanlah bangunan besar tanpa pondasi karena sesungguhnya ketentuan toleransi tersebut secara jelas dan tegas termaktub dalam doktrin asasi Islam.

Ini artinya, setiap pelanggaran atas prinsip toleransi tersebut adalah sebuah ketidaktaatan terhadap Allah yang, tentu saja, akan mendapatkan balasan yang setimpal. Bila dirumuskan secara sederhana bentuk keberagamaan umat Islam bukan eksklusivisme ekstrem atau inklusivisme dan pluralisme, tetapi sebuah ekslusivisme yang memberikan ruang bagi keberadaan kelompok lain secara sosiologis, yaitu eksklusivisme toleran.

\section{Penutup}

Pembahasan kritis terhadap teologi pluralisme agama yang dikembangkan sebagian tokoh pemikir Islam yang punya kecenderungan liberal di atas menghasilkan kesimpulan sebagai berikut. Pertama, gagasan pluralisme agama dibangun atas aksioma bahwa "klaim kebenaran mutlak agama sebagai sebab terjadinya kekerasan dan konflik bernuansa agama." Keberadaan teologi pluralisme agama sendiri dimaksudkan agar umat Islam memiliki sikap beragama yang dialogis dan ramah terhadap perbedaan. Pluralisme agama yang berarti paralelisme agama-agama dalam aspek esoteris dibangun di atas landasan ontologis dualisme realitas: mutlak dan relatif, dan secara epistemologis realitas yang kedua tidak bisa mengenal realitas pertama kecuali dengan simbol-simbol. Basis ontologis dan epistemologis ini kemudian menurunkan teori esoterisme dan eksoterisme: bahwa semua agama yang ada di dunia ini memiliki perbedaan di aspek eksoterisme, namun secara hakiki semuanya bertemu pada wilayah esoterisme. Dalam konteks Islam, titik temu aspek esoterisme agama-agama tersebut terletak pada doktrin keesaan Tuhan (tauhid) dan keharusan penyerahan diri secara mutlak kepadanya. Di titik ini semua agama bertemu dan sama. Perbedaan terjadi pada aspek eksoterik yaitu di bidang syariat.

Kedua, dalam gagasan pluralisme agama terdapat kerancuan konseptual (conceptual confusing) sehingga melahirkan berbagai kontroversi dan penolakan. Dengan berbagai kerancuan tersebut, sesungguhnya teologi pluralisme agama bukanlah tawaran yang solutif untuk meredakan ketegangan dan konflik antar umat beragama. Justru kerancuan itu bisa menimbulkan problem serius bagi keyakinan beragama karena memosisikan kebenaran agama-agama yang ada sebagai paralel. Ini merupakan serangan serius terhadap doktrin agama. Memaksakan gagasan itu untuk terus dipasarkan ke masyarakat Muslim tentu sebuah upaya yang kurang berarti. Bagaimana 
pun juga klaim kebenaran mutlak dalam Islam tidak bisa begitu saja dihapus diganti dengan klaim kebenaran relatif ala pluralisme agama. Untuk itu yang diperlukan sesungguhnya adalah sebuah sikap beragama yang secara tegas meyakini kebenaran agamanya namun tetap ramah dan baik terhadap keberadaan umat agama lainnya.

Ketiga, Islam sendiri secara tegas mengklaim sebagai agama terakhir yang dibawa Nabi Muhammad untuk semua umat manusia. Islam yang dibawa Muhammad memang memiliki titik temu dengan agama-agama yang dibawa rasul-rasul terdahulu. Namun keunggulan Islam menempatkan dirinya sebagai agama yang harus diikuti oleh semua umat, tidak terkecuali umat pemeluk agama para nabi terdahulu. Dengan demikian hanya dalam Islam lah terdapat keselamatan di akhirat kelak. Kekhawatiran terjadinya kekerasan atas nama keunggulan Islam telah diantisipasi secara dini oleh Islam dengan berbagai macam batasan dan aturan yang mengatur umatnya agar tidak mengekspresikan perasaan keunggulannya tersebut secara liar. Adanya larangan mencaci-maki tuhan-tuhan yang disembah umat lain, meski penyembahan tersebut jelasjelas salah dan sesat. Atau larangan menyebarkan Islam dengan paksaan dan larangan memerangi umat lain kecuali sekadar pertahanan diri merupakan contoh aturan-aturan yang mengendalikan umat Islam agar tidak semena-mena mengekspresikan superioritas agamanya untuk menghindari konflik dan kekerasan. Dari sinilah kemudian disimpulkan bahwa Islam adalah agama yang memadukan eksklusivisme dengan toleransi, atau agama yang eksklusif namun toleran.

\section{Pustaka Acuan}

A. Sirry, Mun'im, (ed.). Fiqh Lintas Agama: Membangun Masyarakat Inklusif-Pluralis. Jakarta: Paramadina, 2004.

A. Sirry, Mun'im. "Fatwas and Their Controversy: The Case of the Council of Indonesian Ulama (MUI)," dalam Journal of the Southeast Asian Studies, Vol. 4 4, Issue 1, 2013.

A. Sirry, Mun'im. "Pluralisme Agama," dalam Majalah Ummat, 1 Maret 1999/13 Dzulkaidah 1419.

Abdalla, Ulil Absar. "Keragaman dalam Pandangan Islam," dalam M. Imdadun Rahmat, et al. Islam Pribumi: Mendialogkan Agama, Membaca Realitas. Jakarta: Erlangga, 2003.

Abdalla, Ulil Abshar. Menjadi Muslim Liberal. Jakarta: Nalar, 2005.

Abu Hapsin, Komarudin, dan M. Arja Amroni. "Urgensi Regulasi Penyelesaian Konflik Umat Beragama: Perspektif Tokoh Lintas Agama," dalam Walisongo, Vol. 22, No. 2, 2014.

Al-Faruqi, Ismail Raji, dan Lois Lamya al-Faruqi. The Cultural Atlas of Islam. New York: MacMillan Publishing Company dan London: Collier Mac Millan Publishers, 1986. 
MIQOT Vol. XLII No. 1 Januari-Juni 2018

Al-Qardhâwî, Yûsuf. Islam Inklusif dan Eksklusif, terj. Nabhani Idris. Jakarta: Pustaka alKautsar, 2001.

Amal, Taufik Adnan. "Masalah Keberagamaan di Tengah Keragaman," dalam Abd. Rohim Ghazali dan Saleh Partaonan Daulay (ed.). Muhammadiyah dan Politik Islam Inklusif: 70 Tahun Ahmad Syafii Maarif. Jakarta: Maarif Institute, 2005.

Anonim. Al-Kitab. Jakarta: Lembaga al-Kitab Indonesia, 1988.

Armayanto, Harda. "Kristen-Barat Membangun Kerukunan," dalam Kalimah, Vol. 11, No. 1, 2013.

Bakar, Abu. "Konsep Pengampunan Dosa dalam Kristen Katolik," dalam Toleransi, Vol. 3, No. 2, 2001.

Basya, M. Hilaly. "The Concept of Pluralism in Indonesia: a Study of MUI's Fatwa and the Debate among Muslim Scholars," dalam Indonesian Journal of Islam and Muslim Societies (IJIMS), Vol. 1, No. 1, 2011.

Casram. "Membangun Sikap Toleransi Beragama dalam Masyarakat Plural," dalam Wawasan, Vol. 1, No. 2, 2016.

Fata, Ahmad Khoirul, dan Fauzan, "Kritik INSISTS terhadap Gagasan Pluralisme Agama," dalam Kalam, Vol. 11, No. 1, 2017.

Fata, Ahmad Khoirul. "INSISTS dan Gerakan Anti Liberalisme di Indonesia," dalam Jurnal Kajian dan Pengembangan Manajemen Dakwah, Vol. 04, No. 01, 2014.

Fata, Ahmad Khoirul. "INSISTS dan Gerakan Anti Liberalisme Islam di Indonesia," dalam Jurnal Kajian dan Pengembangan Manajemen Dakwah, Vol. 04, No. 01, 2014.

Gazali, Hatim. "Agama dalam Cetakan Baru," dalam Jawa Pos, 7 Desember 2003.

Ghozali, Abd. Moqsith. "Cetak Biru Toleransi di Indonesia," dalam Jawa Pos, 6 Oktober 2002.

Hanafi. "Eksklusivisme, Inklusivisme, dan Pluralisme: Membaca Pola Keberagaman Umat Beriman," dalam al-Fikra, Vol. 10, No. 2, 2011.

Hick, John. "Religious Pluralism," dalam Mircea Eliade (ed.), The Encyclopedia of Religion, Vol. 11. New York: MacMillan Publ. Comp., dan London: Collier Mac Millan Publ., 1987.

Hidayat, Komaruddin, dan M. Wahyuni Nafis. Agama Masa Depan: Perspektif Filsafat Perennial. Jakarta: Gramedia, 2003.

Hidayat, Komaruddin. "Membangun Teologi Dialogis dan Inklusivistik," dalam Komaruddin Hidayat dan Ahmad Gaus AF (ed.), Passing Over: Melintasi Batas Agama. Jakarta: Gramedia, 2001.

Hilmy, Masdar. et al., "Membedah Anatomi Konflik Agama-Etnik: Rekonstruksi Paradigma Teori dan Resolusi Konflik Agama-Etnik Pasca Orde Baru." Penelitian, Kementerian Riset dan Teknologi dan Lembaga Ilmu Pengetahuan Indonesia, 2004. 
Imam Muslim. Shaḥ̂̂h Muslim, Juz I. Beirut: Dâr al-Kutub al-'Ilmiyyah, 1992.

Jong, Kees de. "Hidup Rukun Sebagai Orang Kristen: Spiritualitas dari Segi Theologia Religionum," dalam Gema Teologi, Vol. 30, No. 2, 2006.

Kimball, Charles. Kala Agama Jadi Bencana, terj. Nurhadi. Bandung: Mizan, 2003.

Kuswanjono, Arqom. "Pluralisme Pancasila," dalam Jurnal Filsafat, Vol. 39 No. 1, 2006.

Legenhausen, Muhammad. Satu Agama atau Banyak Agama: Kajian Tentang Liberalisme dan Pluralisme Agama, terj. Arif Mulyadi. Jakarta: Lentera, 1999.

Madjid, Nurcholish. Cendekiawan \& Religiusitas Masyarakat. Jakarta: Paramadina, 1999.

Madjid, Nurcholish. Islam: Doktrin dan Peradaban. Jakarta: Paramadina, 1992.

Madjid, Nurcholish. "Keluarga Imran, Siti Mayam, dan Isa al-Masih," dalam Komaruddin Hidayat dan Ahmad Gaus AF (ed.), Passing Over: Melintasi Batas Agama. Jakarta: Gramedia, 2001.

Munawar-Rahman, Budhy. Islam Pluralis: Wacana Kesetaraan Kaum Beriman. Jakarta: Paramadina, 2001.

Munthe, Eben. "Dosa Menurut Teologi Paulus," dalam Pneumatikos, Vol. 1, No. 1, 2010.

Nafis, Muhammad Wahyuni. "Referensi Historis Bagi Dialog Antaragama," dalam Komaruddin Hidayat dan Ahmad Gaus AF (ed.). Passing Over: Melintasi Batas Agama. Jakarta: Gramedia, 2001.

Nainggolan, Bartholomeus Diaz. "Dosa Asal Berdasarkan Eksegesis Surat Roma 5: 1221," dalam Koinonia, Vol. 10, No. 2, 2015.

Noer, Kautsar Azhari. “Tuhan Kepercayaan,” dalam Luthfie Assyaukanie (ed.), Wajah Liberal Islam di Indonesia. Jakarta: JIL dan TUK, 2002.

Noorhayati, S. Mahmudah, dan Ahmad Khoirul Fata. "Exclusive Islam From the Perspective of Ibn Taymiyah," dalam Esensia, Vol. 18, No. 2, 2017.

Purnomo, Bagus. "Toleransi Religius: Antara Pluralisme dan Pluralitas Agama dalam Perspektif al-Quran," dalam Suhuf, Vol. 6, No. 1, 2013.

Sarwono, Sarlito Wirawan. "Hubungan Antar Agama dalam Pandangan Psikologi," dalam Devi Setya Wibawa, et al. (ed.). Dialog Antar Agama. Jakarta: Pusat Kajian Pembangunan Masyarakat UNIKA Atma Jaya, 1998.

Sukidi. “Ketika Kebenaran Ditafsirkan,” dalam Jawa Pos, 11 Januari 2004.

Sukidi. Teologi Inklusif Madjid. Jakarta: Kompas, 2001.

Susanto, Happy. "Kritisisme Sejarah Teologi Barat," dalam Tsaqafah: Jurnal Peradaban Islam, Vol. 7, No. 2, 2011.

Tarpin. "Pandangan Kristen tentang Dosa: Asal Muasal dan Cara Menebusnya," dalam Jurnal Ushuluddin, Vol. 16, No. 2, 2010. 
MIQOT Vol. XLII No. 1 Januari-Juni 2018

Tim Penulis Institut Titian Perdamaian. Dinamika Konflik dan Kekerasan di Indonesia. Jakarta: Institut Titian Perdamaian, 2011.

Yunus, Firdaus M. "Konflik Agama di Indonesia," dalam Substantia: Jurnal Ilmu-ilmu Ushuluddin dan Filsafat, Vol. 16, No. 2, 2014, h. 220.

"Sukidi: di Amerika Saya Menemukan Islam," dalam http://islamlib.com, 10 Juli 2005. 